\title{
Missions and the Construction of Gender in the Middle East
}

\section{Introduction}

\author{
Séverine Gabry-Thienpont | ORCID: 0000-0002-7899-5904 \\ CNRs/AMU, Idemec, France \\ severine.gabry-thienpont@cnrs.fr \\ Norig Neveu | ORCID: 0000-0001-9669-5174 \\ CNRS/AMU, Idemec, France \\ neveu@mmsh.univ-aix.fr
}

\begin{abstract}
The introduction to this special issue considers interdisciplinary approaches to the study of gender within missions to the Middle East, from the nineteenth century to the present. By highlighting the piecemeal nature of existing historical and anthropological research, it throws light on the transnational dynamics and gendered constructions of missionary activity, along with its nationalist dimensions. The studies presented here examine long-term gendered constructions of missionary activities in ways that encompass both femininities and masculinities, along with constructions of womanhood and manhood. By putting the question of gender at the heart of their works, the contributors to this special issue affirm the centrality of gendered approaches for understanding the social, cultural and religious relationships between missionaries and local peoples whom they encountered.
\end{abstract}

\section{Résumé}

L'introduction de ce dossier thématique propose une synthèse des orientations prises par les sciences humaines et sociales pour examiner la place du genre au sein du fait missionnaire au Moyen-Orient, du XIX ${ }^{\mathrm{e}}$ siècle à nos jours. Soulignant le caractère parcellaire de la recherche en histoire et en anthropologie sur cette thématique, ce texte met en lumière les dynamiques transnationales, les constructions genrées liées aux démarches socio-éducatives et les objectifs nationalistes à l'œuvre au sein de l'activité 
missionnaire de façon peu ou prou consciente, voire maitrisée. La notion de genre y est mobilisée dans une dimension interactionnelle et connectée, afin d'appréhender sur le temps long les modalités des constructions genrées - dont les féminités et les masculinités - liées à l'action missionnaire. En mettant les problématiques de genre au cœur de leur propos, les autrices affirment le caractère crucial de cette approche pour comprendre la nature des rapports sociaux, culturels et religieux entre missionnaires et missionnés.

\section{Keywords}

Middle-East - missionary work - transnationalism - gender - femininities - masculinities - Westernisation

\section{Mots-clés}

Moyen-Orient - travail missionnaire - approche transnationale - constructions de genre - féminités - masculinités - occidentalisme

Religious missions in the Middle East at the end of the 19th century rarely operated within a mixed-gender context. In the field of medical care, some orders may have permitted men and women to move within the same environment, but overall, missionary activity, whether Catholic, Protestant or Orthodox, was governed by more or less deliberate and idealised notions of gender identification. While it may not be new to consider the missionary act as a gendered phenomenon, this special issue contends that the question has not been fully explored. Moreover, "injecting a gender perspective can shift the viewpoint and reveal blind spots in traditional analyses and lead to a reconsideration of certain aspects of the studied object under a fresh light". ${ }^{1}$ Focusing on the Middle East, this special issue aims to show how gender remains crucial for an examination of the social, cultural and religious relationships between missionaries and the people they encountered. Gender will be understood according to the definition proposed by the anthropologist Perrine Lachenal, as "both the producer and product of learned bodily actions and of processes of subjectivisation". ${ }^{2}$ An examination of the establishment of gender can "highlight the way in

1 Fillieule, Mathieu, Roux (2007), p. 8.

2 Lachenal (2015), p. 21. 
which societies have historically transformed sexual difference between male and female into guidelines around behaviour and competence, and a binary set of multiple and systematic differences between men and women". ${ }^{3}$ Thus, as Joan W. Scott proposes, "one should not concentrate on the roles assigned to men and women but on the construction of sexual difference itself". ${ }^{4}$ Clearly, gender can entail a mode not only of differentiation but also of social stratification. $^{5}$

Throughout the 2oth century, Protestant, Orthodox and Catholic missions, representing different churches and rites and including those with or without religious orders, reorganised town spaces, village spaces and even family spaces in the Middle East. Depending on the institutions to which these missions adhered, even the living arrangements of their agents varied - for example, entailing separate female and male communities in the case of Catholic missions, and often married couples (sometimes with children) among Protestants. The forms and structures of insertion reveal different perceptions of the accompanying gender relationships and systems. In certain cases, the missionaries gained the status of privileged intermediaries within families, while in others they became mediators between individuals as well as with public authorities. What roles did gender identity play within these exchanges, while establishing social and religious norms? More broadly, how did the missions exert an influence on the everyday life of men, women and children, both Christian and Muslim, and what impact did they have on religious and social practices?

Most scholarship on gender and missions has concentrated on Protestant activities, notably in pointing out the strategic role of single and married women in missionary societies (e.g. within the Church Missionary Society). ${ }^{6}$ Published works are clear on this, ${ }^{7}$ and yet the case studies are often histori$\mathrm{cal}$, rarely anthropological and scarcely concern the Middle East. ${ }^{8}$ Nevertheless, they address central issues: women as agents of social reform through education; their role in attempts to manage and control the body; the delivery of practical knowledge through medicine and photography; women's role in

3 Guionnet, Neveu (2021), p. 32.

4 Scott (2009).

5 Bereni and Trachman, 2014.

6 Fleischmann (2003); Flaskerud, Okkenhaug (2005); Fleischmann (2006); Hauser (2015); Ferree Womack (2019).

7 Gulnar (200o); Ardener, Bowie, Kirkwood (1993); Semple (2003); Middleton (2007); Manktelow (2019).

8 Sharkey (2002); Sharkey (2008). 
changing the social dynamics of their countries of provenance and settlement. ${ }^{9}$ As Inger Marie Okkenhaug pointed out in the introduction to the 2010 special issue of this journal entitled Gender and Missions in the Middle East, Catholic and Protestant missions in the Ottoman Empire were socially engaged in two particular fields: education, and care for the sick and destitute. ${ }^{10}$ The missionaries, women and men, became reference points in education and public health, which would have consequences, as we shall see in the following pages. Regarding missionary men, gendered perspectives remain rare, while those that have appeared focus on Catholic orders of men who settled in the Middle East from the 19th century onwards. ${ }^{11}$

In sum, contributors to this special issue consider how mission institutions mobilised gender consciously or inadvertently. Through health, education, social care and humanitarianism, but also via relations between individuals and sometimes through modes of employment, do missionaries embody or spread new gendered conceptions of social roles? Such questions are all the more crucial, in that, since the second half of the 2oth century many local adherents have joined these missions, which were originally staffed by nonnatives. Do these missionaries bring other gendered models and ideas?

Missionary Activity and Gender Issues

After a significant spread of Catholic missions (mainly Jesuit and Franciscan) beginning in the 16th century, one of the peculiarities of the 19th century in the Middle East was the huge growth in Protestant missions, primarily American and British. Within this context, women were sent as nuns, as unmarried protestant missionaries or as wives of missionaries. They worked as teachers, nurses and in the humanitarian sector, and most of them had to deal with the gap that existed between the missionary ideal and real work in a challenging environment. The history of women, gender and missions in the Middle East is one of a complex process of negotiation between personal calling, the demands of the missionary societies and the realities on the ground. ${ }^{12}$

\footnotetext{
$9 \quad$ Murre-van den Berg (2006); Okkenhaug, Nielssen and Hestad (2011).

10 Okkenhaug (2010).

11 Okkenhaug (2005); Verdeil (2016).

12 Okkenhaug (2010).
} 


\subsection{Women Talk to Women, Men Talk to Men}

As mentioned above, it was initially with regard to the Protestant world that the question of the interplay between gender and missionary activity was posed, most probably because of greater accessibility to archives of Protestant missionary societies and the contemporary visibility of the evangelical phenomenon. ${ }^{13}$ While, at the outset, couples were sent on mission to the different regions of the Middle East, from the end of the 19th century hundreds and then thousands of female missionaries were dispatched, fundamentally reshaping the missionary landscape. Young Protestant women from America, Norway, Finland, Germany and Britain gradually settled in, raising questions about the status and actions of women, especially single women, in the role of missionaries. ${ }^{14}$

In 1899 Qasim Amin published The liberation of women (Tahrïr al-mar'a). In a region where the role of women in society was a subject of debate, especially as part of the social, intellectual and religious reform movement known as al$N a h d a,{ }^{15}$ this book was a landmark in asserting the importance of women's education and their independence within modern society. As the issues of the role of women and gender relations were undergoing major reconfiguration, missionaries were shaping and participating in these social changes throughout all eras. ${ }^{16}$ Catherine Mayeur-Jaouen demonstrates in her text that the expansion of female missionary activity in Egypt from the 1940s to 1970s closely linked traditional tasks - schooling and healthcare - and the advancement of women. While missionary presence, both male and female, grew in education, always seen as an essential channel for progress in social and health development, it also appeared to fit into a context that asserted an Orientalist understanding of the Middle East. ${ }^{17}$ Indeed, the status of female missionaries recalls that of women travellers in the Middle East between the 17th and 19th century, who enjoyed genuine freedom of movement and would intrude into local populations. ${ }^{18}$ Their journeys provided alternative readings of the lands and societies they encountered, but they highlighted above all the existence of a female Orientalism. ${ }^{19}$

Dispatching women was initially motivated by the idea that they, in contrast to men, were able to address a mixed audience. For example, in 1886,

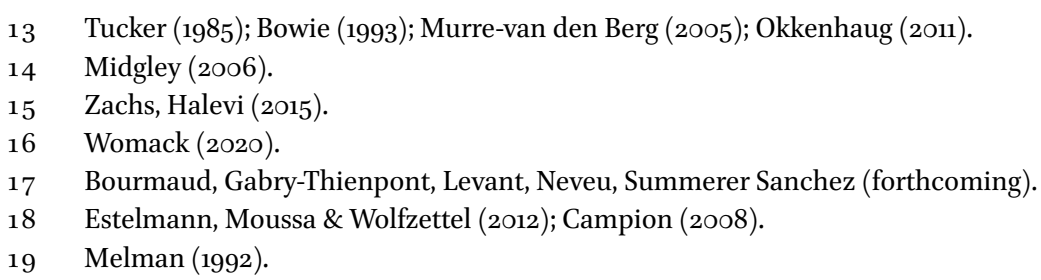


the Methodists William and Jane Lethaby settled in Karak. ${ }^{20}$ They were first housed by 'Awda al-Qusūs, a Greek Orthodox notable of the town, who notes in his memoirs that only Jane Lethaby spoke a few words of Arabic. For several years the couple were the sole members of the mission, which saw the region as strategic to its aims of spreading Protestantism southwards. The Karak missionary team expanded in 1891 with the arrival of Miss Arnold and a couple named Forder, and then in 1892 by Miss Bowyer, a member of the CMS, who had previously worked in Palestine and spoke Arabic. ${ }^{21}$ The mission fell under the authority of the CMS in 1893. In addition to the greater number of female members of the mission, it is their ability to connect with influential locals that this example highlights. According to her letters, Jane Lethaby enjoyed the support of "Muallim Khusus" (probably al-Qusūs), the teacher in the Greek Orthodox school, who provided protection in the absence of her husband and thus helped her to integrate into local social networks. She was also called upon by the town sheikh, Khalīl al-Majālī, to act as his scribe in the writing of a letter in English. The intermediary role played by women with regard to local notables was one of the strengths of the CMS missionary strategy.

The arrival of Protestant missionary women had an effect on the other churches implanted in the Middle East, which reacted by deploying their sisterhoods and encouraging the formation of local orders, such as the Sisters of the Rosary in 1885 . Behind these foundations stood the presence of certain women presented as exemplars, steeped in the ideal of reform, like Mariam Baouardy who was beatified in 1983. Mystics and female figures of local holiness, like Saint Rafqa (1832-1914) in Lebanon also stand out. ${ }^{22}$ Apparitions of the Virgin occurred accompanied by new forms of worship. ${ }^{23}$ The foundation of female orders followed a different timeline from one church to the other: the Melkite Church developed its own female institutions from the 1930s and attracted members of Latin Catholic orders; ${ }^{24}$ the Greek Orthodox Church remained without any female order for a long time, and this has often been considered in scholarly literature as having hampered the development of their social and religious work in the Middle East, further exacerbated by a lower level of Russian missionary activity after the 1917 revolution; in Egypt, the Coptic Orthodox

\footnotetext{
20 Durley (1920).

21 Forder (1902), p. 34. Durley (1920), p. 242.

22 Verdeil (2006). On the mission of Lebanese and Syrian mystics (following in the wake of Rafqa) alongside exclusively male clerical institutions at the turn of the 21st century, see Aubin-Boltanski (2018).

23 Notermans, Jansen, Hermkens (2009); Voile (2004).

24 Neveu (2019).
} 
bishop of Beni Suef founded the Banāt Maryam (Daughters of Mary) in 1963 as a working order of nuns, unlike contemplative sisters secluded in their convents, who were intended to follow the model provided by the Catholic Apostolic Sisters and their works. ${ }^{25}$ Other dioceses were inspired by the Beni Suef example and set up schools, hostels, clinics etc. to be run by active nuns referred to as mukarrasāt. ${ }^{26}$ Each diocese defined its own manner of engaging these consecrated women in tasks to fit the needs of the parishes, but especially to help, first and foremost, other women as part of a female self-help system that was considered to be socially necessary.

Whether Sisters of Mary, Comboni Sisters, Sisters of Sion, Daughters of Charity, Sisters of Nazareth etc., Catholic nuns occupy a central place in the contemporary missionary history of the region despite a lack of visibility in scholarly research. Thanks to recent access to the archives of female Catholic orders, ${ }^{27}$ and the close interplay between history and anthropology (as proposed by Catherine Mayeur-Jaouen in this issue), their role is however becoming ever better documented. The aim of this special issue is to contribute to the endeavour by putting into perspective examples from the Protestant, Catholic and Orthodox worlds in order to understand the gender dynamics that underlay both missionary activity and its social imprint.

The Status of Missionaries, Family Values, and the Management and Control of the Body

At the heart of the gender dynamics linked to the contemporary missionary movement lies the question of the Christian household and the role of men and women within it. In this respect Barbara Reeves-Ellington's work on the Balkans during the Ottoman era has shown that the ideas of gender circulated by missionaries were influenced by the social dynamics of their countries of origin. The author shows that this dialectic is especially embodied by the example of the missionary couple: the women may take on new responsibilities but do not contest their inferior position. It is thus as missionary wives and not missionaries as such that the Americans she studies are presented. ${ }^{28}$ However, as Heather Sharkey reveals, there were gradually more women than men working for Protestant missions outside the United States from the end of the 19th century. ${ }^{29}$

\footnotetext{
25 El-Khawaga (1993), p. 256.

26 From karrasa nafsu, which means "to dedicate oneself to".

27 Summerer-Sanchez (2010).

28 Reeves-Ellington (2013).

29 Sharkey (2010).
} 
In his 1968 study of women in American Protestant missions, the historian R. Pierce Beaver attributed this tendency to three changes that occurred shortly after the Civil War of 1861-1865: American women became better educated, more active in social movements, and they turned to overseas missionary work in search of a career, particularly as teachers, but also as doctors and nurses. While some Presbyterian women joined missions as the wives of missionaries, many others from post-civil war America did so without being married. ${ }^{30}$ Thus, engaging in missionary work led to female career development from the 19th century ${ }^{31}$ onwards, as Heather Sharkey points out in her article. Beginning with examples of American women doctors and Egyptian women evangelicals, the author examines the impact that the American Presbyterian mission in Egypt from 1854 to 1967 had on women in widening the career opportunities of both missionary women and women targeted by missions.

From celibacy and strict separation of the sexes to the consecration of pastor couples, in discussions of sexuality in conformity with dogma and spousal duty, and from manuals governing female attitudes to the control of physical relations between seminarians, missionaries promoted and embodied gendered values in antagonistic ways, always placing marital status and sexuality at the heart of the matter. Sometimes these values altered or even discredited the missionary act, especially in the case of rumours and scandals. ${ }^{32}$ Moreover, sometimes missionary practice and the debates around bodily practices in the host country sowed trouble within the mission, as with the controversies over excision that cut through the CMS in the 1930s. ${ }^{33}$

While the vocation of a mission may be to shape souls, it reflects the ideas of its time in the management and control of the body. Medicine, as a fundamental activity in the establishment of missionary presence, had a central role in this mastering through practices of care and hygiene. ${ }^{34}$ Lastly, from uniforms to sporting activities, as we shall see in Chantal Verdeil's article, the mission also contributed to governing the social and physical presence of the region's inhabitants, as well as their representation and that of their gender. In addition to the religious models conveyed by missionaries, especially that of the Christian household, the issue of the colonial aspect of the mission must be tackled. School photographs from the beginning of the 2oth century are evidence of this: groups of young Egyptians, Palestinians or Lebanese dressed in uni-

\footnotetext{
$30 \quad$ Beaver (1999).

31 Welter (1978); Beaver (1999).

32 Melman (1992).

33 Muray (1976).

34 Bourmaud (2012).
} 
form pose calmly, framed on either side by their North American or European teachers. These photos remind us that missionary hospitals and schools were increasingly directed throughout the 2oth century at a non-Christian clientele. This special issue intends to go beyond an examination of the mission based on terms of its diplomatic implications as a tool of imperialist powers ${ }^{35}$ in the Middle East in order to shed light on the everyday and sustained influence of this presence upon the societies on the receiving end of missionary work. ${ }^{36}$

The marital status of missionaries can throw light on several aspects of the missions: it allows one to read divergent models in the construction of gender relations within missionary work; it documents changes in these relations both in the host country and the country of origin; and lastly it leads one to envisage social constructions that interact with other confessions or with State policies - for example, one might think of the Nasser regime's promotion of contraception. And beyond marriage, single and lay women gradually asserted themselves during the 2oth century to become the majority actors. Catherine Mayeur-Jaouen examines the interweaving of missionary activities and social work involving both nuns and laywomen in Egypt of the 1940s to 1970s. Using case studies mostly situated in Upper Egypt, she shows that the development of female missionary actions resulted from male initiatives in regions exhibiting large social disparities. But above all, she reveals the growing and central role of laywomen, notably after the Second Vatican Council, and especially within youth movements (closely linked to missionary work) such as Justice et Paix, and NGOs like the Association of Upper Egypt. Whether members of support groups, of charitable organisations, of Caritas, or of the French Auxiliaires féminines internationales, the role of lay people, male and female, within the religious domain remains understudied, although they represented, as we shall see, powerful conduits of missionary policy.

\subsection{International Gender Dynamics: towards an Interconnected and Global Approach}

Mobility sits at the very heart of the missionary phenomenon. In addition to individuals, ideas, media and models all circulate, and therefore the issue of language and translation must be tackled. ${ }^{37}$ In the case of the CMS, mastery of Arabic was an important criterion in the posting of women missionaries.

35 Deringil (1997); Bocquet (2006); Makdissi (2007); Verdeil (2007).

36 Hausser, Lindner, Möller (2016).

37 Barbara Reeves-Ellington (2013) mentions, for example, the Mother's Manual by Martha Jane Riggs published in 1842 and translated into Greek, Bulgarian, Armenian and Ottoman Turkish. 
As well as languages for communication, there need be tools for deploying the model of social reform, such as periodical reviews, as Catherine Mayeur-Jaouen explains, and the internet, use of which is examined by Armand Aupiais. Dissemination can go beyond the simple material and physical form of the mission to reach thousands of readers and "views".

This mobility, however, is also and especially transnational. Until the beginning of the 2oth century missions moved primarily from north to south. The importation of gender models and the resultant interactions with authorities and societies of the recipient countries is a very present theme in this issue. Multidisciplinary approaches can shed light on the most recent permutations of these dynamics with the advent of south-south movements. Indeed, during the second half of the 2oth century missionary orders and societies favoured such a dynamic, notably through the recruitment of local missionaries. Armand Aupiais' article presents the migratory experience of missionaries themselves, their promotion of a marital model, and also the development of a discourse on the gendered social role of missionaries from the south which they must adapt for their adherents in a context of migration. This Istanbul case study reflects other regional situations: in Jordan, thousands of female Filipino domestic workers are engaged as Catholics in their parish. Their status as salaried women, most often separated from their family and/or unmarried has upset certain members of the clergy, in that they are outside the family model that conforms to the expectations of the Church. In this respect, Couples for Christ, a lay organisation originally from the Philippines and organised at the regional level, places the role of the couple and the family structure at the heart of its evangelical mission. Its engagement is aimed just as much at migrants in Jordan as it is on the influence that migration has had on family structure in the Philippines. ${ }^{38}$

By contrasting case studies from different Churches, while also taking into account the extent of movements and exchanges of gender regimes on the transnational level, we hope to develop a connected history of gender dynamics linked to missionary work. This involves the reconstitution of these dynamics within local contexts in their relational dimensions with social, economic and political actors. This special issue thus plans to stretch the thinking on the interplay between the phenomenon of migration, gender dynamics and the mission. ${ }^{39}$

38 Field interviews and survey conducted by Norig Neveu and Daphné Caillol, Amman, April-May 2018.

See, for example, Uchem (2014). 


\section{The Social Manufacture of Gender: a Missionary Objective}

The diversification of missionary tools and procedures throughout the past century leads one to consider the missions' objectives in parallel with the educational and charitable initiatives that flourished in the Middle East at the same time. Springing from diverse sources, whether philanthropic societies, NGO s, or community-based initiatives, the creation of hospitals, schools and charitable institutions has spread massively since the beginning of the 2oth century. ${ }^{40}$ Interreligious dialogue has been encouraged, particularly since Vatican II. ${ }^{41}$ Missionaries place themselves in a straightforward visible manner within these initiatives, intimately mixing educational, health, cultural and social programmes. ${ }^{42}$ Based upon this diversity of contexts, actors and objectives, we intend to examine the content and the status of the social construction of gender relations as regards missionaries and the people they act upon.

\subsection{Conjoining Educational Programme and Social Programme}

The CMS very quickly developed a policy of evangelising and educating, especially women, which allowed them to have an influence and an impact on the host population. ${ }^{43}$ One of the motives behind promoting girls' education is that, as future mothers, they would act as conduits of religion in the private sphere, an idea that can be found in the works of Latin Catholic missionaries. These organisations found many imitators in the region.

For example, at the end of the 1820 severend John Lieder of the CMS arrived in Egypt. He considered that school teaching as delivered by the kuttab, or elementary school, was lamentable, solely based upon the intensive memorising of religious texts without encouraging the slightest thought. Furthermore, he deplored the behaviour of both boys and adults, which he qualified in his journal as excessively irreverent. ${ }^{44}$ In the same era, Catholic missionary discourse found support among the same arguments of insufficient education and lack of civility: the teachers and the faithful were ignorant, and to ensure their salvation the Christians needed to be educated. ${ }^{45}$ The kuttab, the preferred institution for teaching young boys in Egypt during the 19th century,

\footnotetext{
$40 \quad$ Naguib, Okkenhaug (2008).

41 Mayeur-Jaouen (2016).

42 Bourmaud, Gabry-Thienpont, Levant, Neveu, Sanchez Summerer (forthcoming).

43 Sharkey (2002) and (2008); Murre-Van den Berg (2005).

44 Sedra (2011), p. 1.

45 Heyberger (1994).
} 
was intimately linked to religion: the Muslims learnt the Quran, and the Christians learnt the Gospels and the alhān, or liturgical melodies. Writing was less important but practised nonetheless through dictation and copying out the Scriptures and Suras. ${ }^{46}$ This was not, however, sufficient for the Protestant and Catholic missionaries: books were to be the divine nourishment of young boys, and all agreed on the development of schooling that was no longer based upon oral culture but on written culture. Paul Sedra has seen in this a barely disguised desire on behalf of the missionaries to depersonalise authority, which was embodied by the holders of orally dispensed knowledge, and thus endow the Egyptians with a secular morality, and, by doing so, cause an upset in power relations to their benefit. ${ }^{47}$

The second half of the 19th century thus witnessed the appearance of singlesex congregational schools, founded by both Catholic and Protestant missionaries. On the local level, this educational land grab did not encounter wholehearted approval. The religious reform movements that swept the region in the second half of the 19th century, in tandem with al-Nahda, wherein the shift to writing also stood as a badge of intellectual legitimacy, bore the desire to compete with the missionary models and to retain their flock within the community fold. In Egypt, Habib Girgis both followed the Protestant missionary model of Sunday Schools and reacted against the expansion of this same form of congregational schooling when, in 1914, he founded the Madāris al-ahad (Sunday Schools) for young Copts in order to rally the youth and turn them into active members of the Church. ${ }^{48}$ Girgis took inspiration for his catechetical method from CMs publications printed at its press in Malta and distributed for free to school pupils in Cairo from the 1820 and used by Protestant missionaries. ${ }^{49}$ In contrast with the kuttāb, the Madāris al-ahad from the very beginning were open to both boys and girls, although teaching was done separately. ${ }^{50}$ Girls over the age of ten years were overseen by women and their meetings had to be conducted independently of the boys. Habib Girgis was clear about this in the rules that he applied to Sunday Schools in 1949: male teachers had in no instance any right to interfere in the supervision of girls, and women were required to provide "suitable" activities, ${ }^{51}$ separate from those of the Coptic Youth League

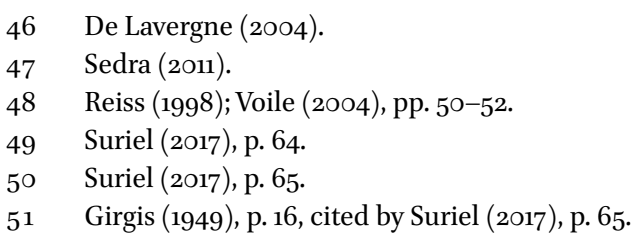


(Jāmi'at al-Shabāb al-Qibțī). Teaching was conducted under a strict regime of separation of the sexes. ${ }^{52}$

This offshoot of the Coptic Orthodox Church, especially dedicated to children, is a fine example of an educational development set up as part of the missionary dynamic linked to teaching. The gender distinction in this schooling was lodged at the heart of educational programmes from the outset, to the extent that it would become a constant, as we shall discover in the articles that follow. However, we shall also see that through teaching the entire social fabric of the nation was targeted for reconsideration and shaping.

\subsection{Forming and Shaping Male Identity}

Missionary ventures did not only pursue their own objectives but were touched by local needs, be they professional, cultural or nationalist. Thus, as the sociologist Raewyn Connell has written, "forms of masculinity are not images, stereotypes or identities, rather they are patterns of social practices, things done, intelligible actions in a historical situation". ${ }^{53}$ Far from being rigid, forms of masculinity are subject to change and to history, and can be reconfigured. By putting into context "that which has long been perceived as constant" ${ }^{\prime 4}$ and understood as a "natural" and ahistorical category, the contributions to this publication analyse the plural constructions of masculinity from a perspective that is attentive to national and transnational circumstances. This construction sits within a "relational reflection on the feminine and the masculine",55 whereby the two categories are considered within their own dynamics as well as through their interactions. While masculine identities must often be read indirectly, in the silences, and "men are most often not forthcoming about the sources and construction of their identity",56 we propose "a gendered rereading of the documentation that has, in the largest part, been left by men". ${ }^{57}$

Thus, Annalaura Turiano analyses the way in which the technical schools of the Salesian mission in Egypt socially formed a worker's masculinity between 1890 and 1939. The author looks at the transmission of masculine ideals via the catechism, theatre and practical workshop apprenticeships provided by the Salesians. Through careful examination of missionary sources, Italian diplomatic documents and published material on Egyptian technical training in

\footnotetext{
$52 \quad$ Girgis (1949).

53 Connell (2014), p. 91.

54 Sohn (2013).

55 Derrien, Giraudier and Gobin (2017).

56 Sohn (2013), p. 24.

57 Lett, Virgili (2018).
} 
the 193os, she reveals these ideals and underlines the major guiding principles of this training: the essential complementarity between piety and discipline. She mentions, for example, the importance attached to punctuality as a measure of the apprentice's success and, by extension, of his profitability. ${ }^{58}$ Turiano also reports on different conceptions of masculinity, wherein multiple values Egyptian, Italian, Catholic, working class and also cosmopolitan - rubbed up against each other and wrestled in order to work out a gendered construction of technical and industrial labour in the service of the nation. The value systems that were instilled worked towards the formation of "good Christians". This close association of piety and discipline also appears in Chantal Verdeil's contribution. She examines the Jesuit missionary schools of Beirut at the dawn of the 2oth century and their colonial project of regeneration in an East that was considered to be decadent. She explores the attempted reformulation of masculine identities through constant contrasting and comparison with Western values. An insistence on modesty and humility suggests that Jesuit teaching at the end of the 19th century put less value on the virile ideal of the masculine body than on purity of soul, whether in the scholastic or artistic domain, via theatre and music, as Turiano also explains in her text. Verdeil notes that quasimilitary athletic training would also be included, but at a later date, during the inter-war period. And lastly, the author studies the masculine identity structured by the Jesuits around a male togetherness, where the female was absent, or, if not, was represented by figures of the warrior martyr (e.g.Joan of Arc) and certain saints, especially Mary, mother figure and guarantor of moral values. At the end of the 19th century, the "good Christian" as drafted by Jesuit teaching in the Lebanese capital was an independent, sensitive, pious and disciplined man.

\subsection{A Gendered Division of Labour}

Starting out from education and training, one can glimpse the content of missionary social actions. The case studies mentioned reveal in effect a gendered division of labour that goes beyond the context of education. The idea that worship should be the responsibility of men, for example, is not an issue among the different churches in the Middle East, and the first female pastor, Rola Sleiman, was nominated in Lebanon in 2017. It is often as benefactors, as founders of chapels or donators of devotional objects etc., that women missionaries appear within the organisation of a denomination.

$5^{8}$ It is noteworthy that this value is also found on the female side, for example with the Daughters of Charity. 
Educational issues, as shown above, were most often governed by the strict separation of the sexes. Women might occasionally manage the education of young boys, as Jane Lethaby did at Karak, but higher education for males, as discussed by Chantal Verdeil, was in the hands of men. ${ }^{59}$ The same applies for the creation and compiling of scholarly work. The place of women in the learned societies that developed in the Middle East, such as those dedicated to biblical studies, was small and primarily involved laywomen enjoying what were often family connections that gave them the chance to make their work public. ${ }^{60}$ The minimal presence of female scholarly work means that today there is little understanding of how these women viewed the East: did they harbour the same Orientalist preconceptions as their male colleagues? The example of the Dominican brother, Antonin Jaussen, and his study of the town of Nablus shows that when missionaries hoped to cast a scholarly eye, in this case ethnographic, on female social life, they were only able to conduct rather superficial observations, mostly through visits to the clinic run by the Sisters of Saint Joseph in Nablus. ${ }^{61}$ Furthermore, while he dedicated two chapters of his monograph to women and their social space, the accompanying photographs reveal just how distanced Jaussen remained from the details of their everyday life: the images are distinctly Orientalist and posed, far from the ethnographic approach claimed by the author. ${ }^{62}$

At the turn of the 2oth century a non-gendered division of scientific work was not a given, and this was clearly not just a phenomenon affecting missionaries; however, such gender dynamics are thrown into focus within this domain, especially as regards the Catholic and Orthodox world. One specific field of science, medicine, is particularly eloquent. As Saint Joseph University established itself as a centre for training future doctors on a regional level, ${ }^{63}$ mission hospitals reflected a double system of domination within the world of work and gender. Missionary men were doctors, while women were nurses. The gradual shift to lay staff in these institutions has provoked changes in the gendered order of the working world. Moreover, women occupy a central position in the modern work category of "care", involving personal assistance and charitable organisations (humanitarian action, healthcare etc.). ${ }^{64}$ Throughout

\footnotetext{
59 On higher education, see also Dupont (2007) and Rabah (2009).

6o Bourmaud, Gabry-Thienpont, Levant, Neveu, Sanchez Summerer (forthcoming).

61 Jaussen (1927); on the clinic of the Sisters of Saint Joseph at Nablus, see Sanchez Summerer (2012).

62 Neveu, Sanchez Summerer (2021).

63 Verdeil (2008).

64 Okkenhaug (2015).
} 
the 2oth century more and more laypersons became engaged and developed confessional associations and NGOS, sometimes with an international reach. These organisations have provided women with opportunities to affirm a certain social standing. This involvement has pushed Middle Eastern societies to respond in an increasingly urgent manner to the demands of donor agencies, embracing the terms and categories of humanitarian action within missionary activity, such as the empowerment of women. While a huge part of missionary activity does not involve wage earning, the very notion shapes the gendered dichotomy of the mission and how this transfers to the level of the jobs ascribed to men and the jobs ascribed to women. Missionary educational initiatives are evidence of this, as in the case presented by Turiano, who highlights the influence of professional schools on the futures of young working class Egyptians. Girls also attended practical courses that most often prepared them to be good wives and good mothers. As we have seen, the model family was at the heart of missionary work, which would have its consequences on a person's relationship with paid labour. In Palestine, young women learn to embroider and are focused towards the performance of unpaid domestic work, sometimes infused with a notion of heritage. As women, they are the guarantors of the family order and of tradition within a nationalist framework of a territory undergoing rapid change. Christian humanitarian actions often reflect these divisions, and yet the work of Ellen Fleischmann has shown that while missionary schools may aim to turn out good family-orientated mothers, a large number of their pupils go on to become paid workers engaged in employment. ${ }^{65}$ Armand Aupiais examines at length the contemporary aspects of this gendered salary arrangement through a detailed analysis of the physical space of churches.

\section{3}

The Representation of Gender and Identity in the Modern Middle East

Issues of women and feminism in the Middle East gained visibility from the beginning of the 2oth century ${ }^{66}$ and evolved in tandem with emerging nationalism. However, academic work has sometimes noted a discrepancy between "a common vision of women in the region as hidden and even oppressed and the emergence of female figures representing a different view".67 This special

\footnotetext{
65 Fleischmann (2010).

66 Al-Ali (2000).

67 Dakhli \& Latte-Abdallah (2010).
} 
issue attempts to reduce the discrepancy by demonstrating the need to consider missions from the viewpoint of gender studies, especially in order to dispose of Orientalist preconceptions and the masculism that still blots various approaches, as well as to reveal the reciprocal play of influence between missions and the socio-political contexts of the host country.

\subsection{The Place of Gender in the Construction of the Nation}

From the beginning of the 2oth century, the women's rights movement advanced in Egypt, with personalities like Huda Sharawi, founder of the Egyptian Feminist Union in 1923. During the inter-war period political discourse projected the expectations of the State upon women and their behaviour: they were seen to embody the nation in Egypt, and the Sate reform project in Turkey. ${ }^{68}$ At the same time feminist counter-arguments emerged. Muslim feminism was born with Zaynab al-Gazālī who founded the Muslim Women's Associations in 1935 (Jama'iyyat al-Sayyidāt al-Muslimāt), which became the Muslim Sisters Association in 1948 and was dissolved in 1964. The study of women's increasing engagement in political and feminist movements is experiencing a revival today, especially around the critical understanding of the "Muslim woman", too often presented as a homogeneous group. ${ }^{69}$

As a result of these local and European women's movements (the two often following similar trajectories during the period, with demands for new social and political rights ${ }^{70}$ ), the condition of women has also become an expressed concern within Catholicism, notably conveyed in the locally published press. For example, Catherine Mayeur-Jaouen records the appearance in the 196os of a small women's section in the Egyptian Catholic magazine Haqluna, which, in reality, says more about the ideal Catholic family than about women as such. ${ }^{71}$ This ideal emphasises care and education. From the family unit to the public sphere, many female missions convey this humanitarian and social ideal, each with its own itinerary more or less adapted to the context. As regards the Sisters of Saint Vincent de Paul, not all of their houses - the term used to designate a community of the Daughters of Charity - follow exactly the same missionary model. Those of Sedfa (Saint Louis) and of Qusiya (Bayt al-Sayyida), both located in Upper Egypt and founded in the 1950s in places considered to be below the poverty line, combine three endeavours: women's advancement,

68 Baron (2005); Badran (1995).

69 See, for example Badran and Cooke (1990); Hopkins (2001); Dayan-Herzbrun (2005); Hanna (2005); Dakhlia (2014); Abu-Lughod (1998); Abu-Lughod (1987).

70 Dakhli, Latte-Abdallah (2010).

71 Mayeur-Jaouen (2018), pp. 186-189. 
schooling for children of Christian families in need, and healthcare through clinics. The attention lavished on these three areas of intervention is specific to the rural environment. The mission of the house of Saint Vincent de Paul in Cairo is teaching, from early childhood through to high school graduation, and all the effort of the four resident nuns is engaged to that end. The Sister Servant, Sister Amira, is director of the establishment and works closely with Sister Nagla, who is in overall charge of the teaching offered at the mission. Sister Nagla is concurrently working on her $\mathrm{PhD}$ thesis through Cairo University, comparing the educational reform programmes implemented in private schools in France and Egypt. Sister Josephine, a Lebanese Maronite, manages the logistics of the establishment; bed and board for sisters and guests, children's meals for those who are considered too poor to be able to bring a snack for the break at 11 am etc. Sister Thérèse, a Catholic convert from Coptic Orthodoxy, supervises the children and teaches catechism.

This institution is coloured by a particular value system that can be sensed in the prayer that the pupils recite together every morning:

My Lord, I offer my day to you,

Bless me and help me to love my work, to remain pure, and commit no sin,

Protect my parents, my country and my school,

And help me to die with all that I need to go to heaven.

This prayer is said in French by the roughly 5 oo pupils in the school, from their earliest years until they are seventeen years old. It summarises in a few phrases the values instilled into the young girls: perseverance and diligence in work; and purity. It takes into account the parents, for whom the girls ask God's protection, and then the country, and lastly the school. It pleads that the life of everyone be exemplary and will contain all the qualities required to gain access to heaven.

This combination of purity of body and soul, and devotion to one's country can certainly be seen from a political viewpoint, but also in terms of the history of female engagement in the Middle East. It has been mentioned: women's issues were spurred on by the interweaving of activist demands at the beginning of the previous century and a religious revival, in which women (lay and religious) were involved. ${ }^{72}$ Certain religious figures then appeared as loaded with significance and were mobilised to take sides, whether religious or secular. Hence Walter Armbrust chose to illustrate an article on the martyrs of 2011 with 
a photograph of a drawing by Hilmī al-Tūni showing the smiling face of a young activist of 23 years, Sally Zahran, who was beaten to death during the events. The caption reads, "Sālī Zahrān, Jeanne d'Arc al-mașriyya, shahīda țawra alšabāb" (Sally Zahran, Egyptian Joan of Arc, martyr of the youth revolution). The reference to Joan of Arc, a symbol of French Catholic female engagement in support of her country, was already present in Egypt of the 19th century, as Marylin Booth has noted. Indeed, she has dedicated a whole chapter to the use of Joan of Arc, especially in the press, to illustrate "love of the nation". ${ }^{73}$ The example of Sally Zahran shows the current relevance of a 15th century martyr who was burnt at stake for her country. But beyond any religious references, these engagements can be seen alongside female activists like May Ziadeh, a Lebanese immigrant to Egypt, who, in an article published in 1926, made the case for female education and for true independence for women in their choice of lifestyle. ${ }^{74}$ She is also linked to the actions of certain young women in Mandated Syria, including Nazik al-Abid, who was involved in the modernist project launched by Prince Faisal. Throughout the first half of the 2oth century, alAbid strove for the social and political emancipation of women, combining women's engagement for the nation with charitable organisations. ${ }^{75}$ However, women's issues were not the only ones to be conjoined with devotion to the nation: the same notion can also be found in Chantal Verdeil's article below, when she examines masculine patriotism through the prism of al-Nahda and the emergence of nationalism. The author points out the Jesuit preference for the figure of a martyr dying for her faith, rather than that of the strong, athletic and commanding man, which was fashionable at the same period in Protestant institutions. To what extent did the gender issue when faced with that of nationalism shape missionary action within the tangled web of politics and contemporary religious reformism? When examined in their multiplicity, these attempts at female (or more widely, gendered) schooling and mentoring show how aims and motives overlap and are all part of an overall dynamic linked to the contemporary politico-religious context in the Middle East.

\subsection{Representations of the Self and of Others: a Tendency towards Westernisation?}

Nationalism expressed through a value system of religious, community, identity and gendered values can be associated, perhaps paradoxically, to missionary Westernisation.

\footnotetext{
73 Booth (2001), p. 233 .

74 Dakhli, Latte Abdallah (2010).

75 Thompson (2011).
} 
The scene is the Saint Vincent de Paul house in Cairo in February 2020 during a Year 2 primary school class. The French teacher is presenting a reading comprehension lesson. Today the subject is holidays: Nicholas, thirteen years old, spends his holidays with his family in the countryside where his grandparents live. Their house is in a big forest where they can enjoy swimming and fishing in a river. Nicholas and his sister feed the rabbits and the chickens with their grandmother. They dig up vegetables from the kitchen garden, help milk the cows, go on picnics, and ride horses and bicycles. From this text the little Year 2 girls learn the vocabulary of the countryside and raise their hands up high, rattling their chairs, as they try to answer the teacher's questions. The same day, during the Year 5 class, another teacher of French begins with dictation: the task is to reproduce a description of buildings. The atmosphere is calmer, the girls are concentrated, and some try discreetly to cheat by looking at their neighbour's work. The dictation describes a house with a pitched roof and windows decorated with boxes of flowers. A small paved path bordered by a green grassy lawn connects the front door to the wrought iron garden gate. The windows have coloured curtains, and the interior upholstery is flowery. Rather than depicting an average Egyptian home, this house, like the countryside in the previous class, recalls images to be found in European children's books of the 1950s to 1970s. The Daughters of Charity in the Saint Vincent de Paul house are not the only ones to draw upon this type of literary resource: other schools and cultural centres run by Franciscans and by Coptic Catholics in Middle and Upper Egypt present the same aesthetic ideals. For example, during a visit in February 2013 by the Coptic Catholic bishop of Assiut to a Markaz tallim, a teaching centre located in his diocese, the staff (laywomen and Catholic nuns) laid out the little girls' work according to the major subject areas presented by the centre: one of these was the family. As a display, the young girls had chosen to create the interior of a house in three dimensions using coloured paper, crayons and bits of fabric: a living room with two armchairs, a rectangular dining table with six high-backed chairs, a double bed with spring mattress, a wardrobe, a dressing table with mirror and, of course, mother and father on either side of the bed. This model, designed to illustrate a family environment, revealed how the young girls' imaginations had been tainted by similar images as those of the Cairo school pupils.

The choice of this text or that illustration demonstrates a particular aesthetic pattern that is closely and systematically associated to educational objectives. When examining the learning of French in Egypt during the 193os, Frédéric Abecassis entertained the notion of a model "defined as the meeting point between the aspirations of a power or a State to hold a monopoly on formal schooling and the market forces expressing families' opinions on the soundness 
of such an education". ${ }^{76}$ The selected aesthetic model in teaching the French language, and more generally in the education offered by Catholic orders displays a tendency towards Westernisation and could therefore be defined as a "symbolic trade commodity".77 Westernisation, associated by word and image to a model of progress and modernity, represents an idealised and fantasised view of the West, fed on stereotypes and a Eurocentric notion of value systems. Europe is the cradle of the Catholic orders mentioned in our examples, just as it is perceived as the continent of "progress", the source of enlightened values: liberty, equality, and justice among others. ${ }^{78}$ Teaching emerges as the vector for transmitting these values for social ends, and hence the reason why parents choose these establishments and why pedagogical programmes turn out to be largely gendered. As regards women, many Catholic nuns will assert that the education of girls is their mission. It will allow the girls to gain their freedom, to take account of human values, of respect (for their bodies and those of others), and shape their mentality in order to better develop their personality in the current socio-political context of the Arab world..$^{79}$ The mission is, in the end, to form "good" Christian boys and girls according to reference models in which Westernisation is conspicuously obvious.

Using regional case studies combining history and anthropology, the contributions to this special issue are an invitation to consider gendered models of the male and female on different levels through the phenomenon of the mission. They can help us to understand the evolution of gendered social functions and assess them, with regard to the place occupied by missions in the everyday lives of individuals in the Middle East from the 19th century to the present day.

\section{Bibliography}

Abécassis, Frédéric. (2006). L'enseignement français en Égypte dans les années 1930: les dévaluations contraintes d' un modèle. In: Cabanel, Patrick, ed., Une France en Méditerranée. Écoles, langue et culture françaises, XIXe-XXe siècles. Paris: Creaphis, pp. 279-302.

Abu-Lughod, Lila, ed. (1998). Remaking women: Feminism and modernity in the Middle

East. Princeton: Princeton University Press.

76 Abecassis, 2006: 280.

77 Id.

78 Roussillon, 2004.

79 Sister Nagla, personal communication, Cairo, February 2020. 
Abu-Lughod, Lila. (1987). Veiled sentiments: Honor and poetry in a Bedouin society. Berkeley: University of California Press.

Al-Ali, Nadje. (200o). Secularism, Gender and the State in the Middle East. The Egyptian Women's Movement. Camdridge: Cambridge University Press.

Ardener, Shirley, Bowie, Fiona; Kirkwood, Deborah, eds. (1993). Women and Missions: Past and Present, Anthropological and Historical Perceptions. Oxford: Berg.

Armbrust, Walter. (2013). The Ambivalence of Martyrs and the Counter-revolution. In: Hot Spots, Fieldsights, May 8. https://culanth.org/fieldsights/the-ambivalence-of -martyrs-and-the-counter-revolution

Aubin-Boltanski, Emma. (2018). Le corps de la Passion. Expériences religieuses et politiques d'une mystique au Liban. Paris: Éditions EHEss.

Badran, Margot. (1995). Feminists, Islam, and Nation. Gender and the Making of Modern Egypt. Princeton: Princeton University Press.

Badran, Margot and Cooke, Miriam. (1990). Opening the Gates, Bloomington: Indiana University Press.

Baron, Beth. (2005). Egypt as a Woman. Nationalism, gender and politics. Berkeley: University of California Press.

Beaver, Pierce. (1968). All Loves Excelling American Protestant Women in World Mission. Grand Rapids, Michigan: William B. Eerdmans Publishing Co.

Bereni, Laure and Trachman, Mathieu, eds. (2014). Le genre, théories et controverses. Paris: PUF.

Bocquet, Jérôme. (2006). Missionnaires français en Terre d'islam, Damas (1860-1914). Paris: les Indes Savantes.

Booth, Marilyn. (2001). May Her Likes Be Multiplied: Biography and Gender Politics in Egypt. Berkeley/Los Angeles: University of California Press.

Bourmaud, Philippe. (2012). Discipline et familiarisation à travers la médecine: une mission médicale à Gaza (1878-1814), Histoire et Missions Chrétiennes 21, pp. 81102.

Bourmaud, Philippe; Gabry-Thienpont, Séverine; Levant, Marie; Neveu, Norig and Sanchez-Summerer, Karène, eds. (forthcoming). Missions chrétiennes et productions des savoirs au Moyen-Orient, XIX ${ }^{\mathrm{e}}-\mathrm{XX}^{\mathrm{e}}$ siècle. In: Bourmaud, Philippe; Gabry-Thienpont, Séverine; Levant, Marie; Neveu, Norig \& Sanchez-Summerer, Karène, In partibus fidelium, Missions du Levant et connaissance de l'Orient chrétien (XIXe-XXIe siècles). Roma: Presses de l'EFR.

Bowie, Fiona. (1993). Introduction: Reclaiming Women's Presence. In: Bowie, Fiona; Kirkwood, Deborah and Ardener, Shirley. Women and Missions: Past and Present: Anthropological and Historical Perceptions. Providence, R.I.: Berg, pp. 1-22.

Campion, Renée. (2008). 'Voyageuses en Orient': Trois pionnières françaises (la Comtesse de la Ferté Meun, la Baronne de Minutoli, Ida Saint Elme). Astrolabe, May/June, online. 
Connell, Raewyn. (1996). Teaching the boys: new research on masculinity, and gender strategies for schools, Teachers College Record 98 (2), pp. 206-235.

Connell, Raewyn. (2014). Masculinités. Enjeux sociaux de l'hégémonie. Paris: Éditions Amsterdam.

Dakhli, Leyla and Latte Abdallah, Stéphanie, eds. (2010). Un autre regard sur les espaces de l'engagement: mouvements et figures féminines dans le Moyent-Orient contemporain, Le Mouvement Social, 231/2, pp. 3-7.

Dakhli, Leyla. (2010). Beyrouth-Damas, 1928: voile et dévoilement, Le Mouvement Social, 231/2, pp. 123-140.

Dakhlia, Jocelyne. (2014). L'historiographie du Harem au Maghreb: la fin d' une histoire des femmes?, NAQD, 2 (Hors-série 3), pp. 191-209.

Dayan-Herzbrun, Sonia. (2005). Femmes et politique au Moyen-Orient. Collection "Bibliothèque du féminisme". Paris: L'Harmattan.

Deringil, Selim. (1998). The Well-Protected Domains: Ideology and the Legitimation of Power in the Ottoman Empire, 1876-1909. London: I.B. Tauris.

Derrien, Marie; Giraudier, Fanny and Gobin, Charlotte. (2017). Introduction - Penser l'engagement en temps de guerre au prisme du genre (XVI-XXI ${ }^{\mathrm{e}}$ siècle), Genre et Histoire 19, spring.

Dupont, Anne-Laure. (2007). Une école missionnaire et étrangère dans la tourmente de la révolution constitutionnelle ottomane: la crise de 1909 au Syrian Protestant College de Beyrouth, Cahier de la Méditerranée 75, pp. 39-57.

Durley, Thomas. (1920). Lethaby of Moab, A Record of Missionary Adventure, Peril, and Toil, Londres; Edimbourg: Marshall Brothers.

El-Khawaga, Dina. (1993). Le renouveau copte: la communauté comme acteur politique, unpublished Ph.D. dissertation in political sciences, Institut d'études politiques.

Estelmann, Frank, Moussa, Sarga and Wolfzettel, Friedrich. (2012). Voyageuses européennes au XIXe siècle: Identités, genres, codes, Paris: PU Paris-Sorbonne.

Ferree Womack, Deanna. (2020). Protestants, Gender and the Arab Renaissance in Late Ottoman Syria. Edinburgh: Edinburgh University Press.

Fillieule, Olivier, Mathieu, Lilian and Roux, Patricia, eds. (2007). Introduction, Politix 78 (2), pp. 7-12.

Flaskerud, Ingvild and Okkenhaug, Inger Marie. (2005). Gender, religion and change in the Middle East: two hundred years of history. Oxford/New York: Berg.

Fleischmann, Ellen L. (2003). The Nation and Its 'New' Women: the Palestinian Women's Movement, 1920-1948. Berkeley: University of California Press.

Fleischmann, Ellen L. (2006). Evangelization or Education: American Protestant Missionaries, the American Board, and the Girls and Women of Syria (1830-1910). In: Van der Murre, Heleen, ed., New Faith in Ancient Lands: Western Missions in the Middle East in the Nineteenth and Early Twentieth Centuries. Leiden: Brill.

Fleischmann, Ellen L. (2010). Lost in Translation: Home Economics and the Sidon Girls' School of Lebanon, c. 1924-1932, Social Sciences and Missions 23 (1), pp. 32-62. 
Forder, Archibald. (1902). With the Arab in Tent and Town. An Account of Missionary Word and Experiences in Moab and Edom and the First Journey into Arabia from the North. London: Marshall Brothers.

Girgis, Habib. (1949). al-QQ̄nūn al-asāsī li-madāris al-aḥhad al-qibṭiyya al-urthūhuksiyya wa-Ğāmi'at al-šabāb al-šibțī bi-al-kirāza al-Murqusìya, Cairo.

Guionnet, Christine and Neveu, Erik. (2004). Féminins/Masculins. Sociologie du genre. Paris: Armand Colin.

Gulnar, Francis-Dehqani. (2000). CMs Women Missionaries in Persia: Perceptions of Muslim Women and Islam, 1884-1934. In: Ward, Kevin and Stanley, Brian, eds., The Church Mission Society and World Christianity, 1799-1999. Richmond: Curzon Press, pp. 91-119.

Hanna, Nelly. (2005). Sources for the Study of Slave Women and Concubines in Ottoman Egypt. In: A. el Azhary Sonbol, eds. Beyond the Exotic, Women's Histories in Islamic Societies. Syracuse, N.Y.: Syracuse University Press.

Hauser, Julia. (2015). German Religious Women in Late Ottoman Beirut. Competing Missions. Leiden: Brill.

Hauser, Julia, B. Lindner, Christine and Möller, Esther, eds. (2016). Entangled Education. Foreign and Local Schools in Ottoman Syria and Mandate Lebanon (19-2oth Centuries). Beirut/Würzburg: Orient Institut/Ergon.

Heyberger, Bernard. (1994). Les Chrétiens du Proche-Orient au temps de la Réforme catholique (Syrie, Liban, Palestine, XVIIe-XVIIIe s.). Roma: École Française de Rome.

Hopkins, Nicholas S., ed. (2003). The new Arab family 24 (1-2). Cairo: American University in Cairo Press.

Jaussen, Antonin. (1927). Coutumes palestiniennes. I. Naplouse et son district. Paris: Geuthner.

Lachenal, Perrine. (2015). Self-défense féminine dans le Caire en révolution: Techniques du genre et jeux de violence, unpublished Ph.D. dissertation, Université Aix-Marseille.

De Lavergne, Nicolas. (2004). L'État et le kuttâb: une analyse de la statistique scolaire égyptienne naissante (1867-1915), Annales islamologiques 38, pp. 371-404.

Lett, Didier and Virgili, Fabrice. (2018). Conclusion. Faire une histoire sans hommes et sans femmes est décidément impossible. In: Sohn, Anne-Marie, eds., Une histoire sans les hommes est-elle possible? Genre et masculinité. Lyon: ENs Éditions, pp. 359368.

Makdisi, Ussama. (2007). Artillery of heaven: American missionaries and the failed conversion of the Middle East. Ithaca: Cornell University Press.

Manktelow, Emily J. (2019). Forging the Missionary Ideal: Gender and the Family in the Church Missionary Society Gleaner, Journal of Religious History 43 (2), pp. 195216.

Mayeur-Jaouen, Catherine. (2016). Le Vatican II des catholiques égyptiens, Archives de sciences sociales des religions 175 , pp. 361-386. 
Mayeur-Jaouen, Catherine. (2018). “Une revue catholique d'Égypte à l' époque nassérienne", Annales islamologiques 52, pp. 159-192.

Melman, Billie. (1992). Women's Orients: English Women and the Middle East, 1718-1918; Sexuality, Religion and Work. Ann Arbor: University of Michigan Press.

Middleton, Angela. (2007). Silent Voices, Hidden Lives: Archaeology, Class and Gender in the CMs Missions, Bay of Islands, New Zealand, 1814-1845. International Journal of Historical Archaeology 11, pp. 1-31.

Midgley, Clare. (2006). Can Women be Missionaries? Envisioning Female Agency in the Early Nineteenth-Century British Empire, Journal of British Studies 45, April, pp. $335^{-358 .}$

Murray, Jocelyn. (1976). The Church Missionary Society and the "Female Circumcision" Issue in Kenya 1929-1932. Journal of Religion in Africa 8 (2), pp. 92-104.

Murre-van den Berg, Heleen. (2005). Nineteenth-century Protestant Missions and Middle-Eastern Women: an overview. In: Okkenhaug, Inger Marie and Flaskerud, Ingvild, eds., Gender and Change in the Middle East, Two Hundred years of History. Oxford/New York: Berg, pp. 103-122.

Murre-van den Berg, Heleen. (2006). New faith in ancient lands. Western missions in the Middle East in the nineteenth and early twentieth centuries. Studies in Christian Mission 32. Leiden: Brill.

Naguib, Nefissa and Okkenhaug, Inger Marie, eds. (2007). Interpreting Welfare and Relief in the Middle East. Leiden: Brill.

Neveu, Norig. (2019). Between uniatism and Arabism: missionary policies and diplomatic interest of the Melkites in Jordan during the Interwar period. Social Sciences and Mission, Special Issue: Missions, Powers and Arabization 32 (3-4), pp. 361-392.

Neveu, Norig and Summerer-Sanchez, Karène. (2021). The Dominicans' photographic collection in Jerusalem: Beyond a Catholic perception of the Holy Land?. In. SanchezSummerer, Karène and Zananiri Sari, Imaging and imagining Palestine - Photography, modernity and the biblical lens (1918-1948). Leiden: Brill.

Notermans, Catrien, Jansen, Willy and Hermkens, Anna-Karina, eds. (2009). Moved by Mary, The Power of Pilgrimage in the Modern World. London: Routledge.

Okkenhaug, Inger Marie. (2005). To give boys energy, manliness and Self-command in Temper:The Anglikan Male Ideal and St George School in Jerusalem, c. 190o-1940. In Okkenhaug, Inger Marie and Flaskerund, Ingwild, eds., Gender religion and change in the Middle East: two hundred years of History. Oxford/New York: Berg, pp. 47-65.

Okkenhaug, Inger Marie, ed. (2010). Gender and Missions in the Middle East, Social Sciences and Mission, Special Issue 23 (1).

Okkenhaug, Inger Marie, Nielssen, Hilde and Hestad-Skeie, Karina, eds. (2011). Protestant Mission and Local Encounters in the Nineteenth and Twentieth Centuries. Leiden: Brill.

Okkenhaug, Inger Marie. (2015). Religion, relief and humanitarian work among Arme- 
nian women refugees in mandatory Syria, 1927-1934. Scandinavian Journal of History 40 (3), pp. $43^{2-454}$.

Rabah, Makram. (2009). A campus at War: Student Politics at the American University of Beirut 1967-1975. Beirut: Dar Nelson.

Reeves-Ellington, Barbara. (2013). Domestic Frontiers. Gender, reform, and American interventions in the Ottoman Balkans and the Near East (1831-1908). Amherst: University of Massachusetts Press.

Reiss, Wolfram. (1998). Erneuerung in der Koptisch-Orthodoxen Kirche. Lit Verlag: Hambourg.

Roussillon, Alain. (2004). L' Occident dans l'imaginaire des hommes et des femmes du Machreq et du Maghreb, Vingtième Siècle. Revue d'histoire 82, pp. 69-79.

Sanchez Summerer, Karène. (2010). Ouvrir les trésors de la charité aux enfants dévoyés d'Abraham - L'action éducative des sœurs de Sion en Palestine ottomane et mandataire (186o-1948). In: Bocquet, Jérôme ed., Judaïsme, école et mission en Méditerranée à l'heure colonial. Rennes: Presses universitaires de Rennes, pp. 207-238.

Sanchez Summerer, Karène. (2012). Réception et impacts de l' action éducative et sanitaire des sœurs de Saint Joseph (Naplouse) et des sœurs de Sion (Jérusalem) par les populations musulmanes rurales et urbaines (1870-1940). In: Beligand, Nadine and Bourmaud, Philippe, eds., Histoire et Missions chrétiennes 22. Paris: Karthala, pp.163196.

Scott, Joan W. (2012). De l'utilité du genre, (translate from English (United States) by Claude Servan-Schreiber). Paris: Fayard.

Sedra, Paul. (2011). From Mission to Modernity: Evangelicals, Reformers and Education in Nineteenth Century Egypt. New York: I.B. Tauris.

Semple, Rhonda Anne. (2003). Missionary Women: Gender, Professionalism and the Victorian Idea of Christian Mission. New-York: Boydell.

Sharkey, Heather J. (2002). Christians among Muslims: The Church Missionary Society in the Northern Sudan, The Journal of African History 43 (1), pp. 51-75.

Sharkey, Heather J. (2008). Civilizing Women: British Crusades in Colonial Sudan, The Journal of African History 49 (2), pp. 333-335.

Sohn, Anne-Marie, ed. (2013). Une histoire sans les hommes est-elle possible? Genre et masculinités. Lyon: ENs Éditions.

Suriel Bishop. (2017). Habib Gigrgis, Coptic Orthodox Educator and a Light in the Darkness. New-York: St Vladimir's Seminary Press/SACPress.

Tucker, Ruth A. (1985). The Role of Bible Women in World Evangelism. Missiology: An International Review 13 (2), pp. 136-146.

Thompson, Elizabeth. (2011). Le mouvement féminin et l'essor de l'État-providence colonial en Syrie (1920-1946), Clio. Femmes, Genre, Histoire [Online] 33, pp. 107-124.

Uchem, Rose. (2014). Women as Migrants and Missionaries. Mission Studies 31, pp. 319339 . 
Verdeil, Chantal. (2006). Le corps souffrant de Rifqâ, sainte maronite du XIX ${ }^{\mathrm{e}}$ siècle, REMMM 113-114, pp. 247-264.

Verdeil, Chantal. (2007). La classe "sous le chêne" et le pensionnat: les écoles missionnaires en Syrie (186o-1914) entre impérialisme et désir d'éducation, Outre-Mers, revue d'histoire 334-335, pp. 197-222.

Verdeil, Chantal. (2008). Naissance d' une nouvelle élite ottomane. Formation et trajectoires des médecins diplômés de Beyrouth à la fin du XIX ${ }^{\mathrm{e}}$ siècle. Revue des mondes musulmans et de la Méditerranée 121-122, pp. 217-237.

Verdeil, Chantal. (2016). Martyrs de la foi catholique, combattants de l'Église romaine: les héros du théâtre de l'Université Saint Joseph de Beyrouth. In: Hauser, J., Lindner, C.B. and Moeller, E. (eds), Entangled Education. Foreign and Local Schools in Ottoman Syria and Mandate Lebanon (19-2oth Centuries). Wurzburg: Ergon, pp. 181199.

Voile, Brigitte. (2004). Les coptes d'Égypte sous Nasser - Sainteté, miracles, apparitions. Paris: CNRs Éditions.

Welter, Barbara. (1978). She Hath Done What She Could: Protestant Women's Missionary Careers in Nineteenth-Century America. America Quarterly 30 (5), pp. 624-638.

Zachs, Fruma and Halevi, Sharon. (2015). Gendering Culture in Greater Syria:Intellectuals and Ideology in the Late Ottoman Period. London: I.B. Tauris. 